\title{
Use of potassium iodide in Dermatology: updates on an old drug ${ }^{*}$
} Uso do iodeto de potássio na Dermatologia: considerações atuais de uma droga antiga

\author{
Rosane Orofino Costa ${ }^{1}$ \\ Aline Carvalhal ${ }^{3}$
}

\author{
Priscila Marques de Macedo² \\ Andréa Reis Bernardes-Engemann ${ }^{4}$
}

\begin{abstract}
Potassium iodide, as a saturated solution, is a valuable drug in the dermatologist's therapeutic arsenal and is useful for the treatment of different diseases due to its immunomodulatory features. However, its prescription has become increasingly less frequent in dermatology practice. Little knowledge about its exact mechanism of action, lack of interest from the pharmaceutical industry, the advent of new drugs, and the toxicity caused by the use of high doses of the drug are some possible explanations for that. Consequently, there are few scientific studies on the pharmacological aspects, dosage and efficacy of this drug. Also, there is no conventional standard on how to manipulate and prescribe the saturated solution of potassium iodide, which leads to unawareness of the exact amount of the salt being delivered in grams to patients. Considering that dosage is directly related to toxicity and the immunomodulatory features of this drug, it is essential to define the amount to be prescribed and to reduce it to a minimum effective dose in order to minimize the risks of intolerance and thus improve treatment adherence. This review is relevant due to the fact that the saturated solution of potassium iodide is often the only therapeutic choice available for the treatment of some infectious, inflammatory and immune-mediated dermatoses, no matter whether the reason is specific indication, failure of a previous therapy or cost-effectiveness.
\end{abstract}

Keywords: Iodine; Potassium iodide; Skin diseases; Therapeutics

Resumo: Iodeto de potássio, sob a forma de solução saturada, é um valioso medicamento no arsenal terapêutico do dermatologista. É usado há mais de um século e útil para doenças de fisiopatologias diversas em virtude de seu caráter imunomodulador. Prescrevê-lo, entretanto, tem se tornado cada vez menos frequente na prática dermatológica. O pouco conhecimento sobre seu exato mecanismo de ação, o desinteresse da indústria farmacêutica com o advento de novos fármacos, além da toxicidade do medicamento pelas altas doses utilizadas são algumas das possíveis justificativas. Dessa forma, os estudos científicos envolvendo seus aspectos farmacológicos, posológicos e de eficácia são relativamente raros. Consequentemente, não se convencionou uma padronização na forma de manipular e prescrever a solução saturada de iodeto de potássio, o que causa um verdadeiro desconhecimento da dose exata em gramas do sal que está sendo fornecida aos pacientes. Ao considerar que a dose está diretamente relacionada à toxicidade e o conhecimento da característica imunomoduladora dessa droga, é importante definir a quantidade a ser fornecida, reduzindo-a até a dose mínima eficaz, de forma a diminuir a intolerância e melhorar a adesão ao tratamento. A relevância do tema se deve ao fato da solução saturada de iodeto de potássio ser, muitas vezes, a única escolha na terapêutica disponível para o tratamento de algumas dermatoses de origem infecciosa, inflamatória ou imunomediada, quer por indicação específica, por falha de outro medicamento ou por seu custo acessível.

Palavras-chave: Dermatopatias; Iodo; Iodeto de potássio; Terapêutica

Received on 17.12.2012.

Approved by the Advisory Board and accepted for publication on 04.01.2013.

Work conducted at the Mycology Laboratory of the Dermatology Service, Hospital Universitário Pedro Ernesto (Pedro Hernesto University Hospital), Universidade do Estado do Rio de Janeiro (Rio de Janeiro State University) - HUPE-UERJ - Rio de Janeiro (RJ), Brazil.

Conflict of interest: None

Financial Support: None

PhD - Associate Professor of Dermatology, Faculdade de Ciências Médicas (Faculty of Medical Sciences), Universidade do Estado do Rio de Janeiro - UERJ (Rio de Janeiro State University) - Rio de Janeiro (RJ), Brazil.

MSc student, Graduate program in Medical Sciences - Universidade do Estado do Rio de Janeiro (UERJ) - Rio de Janeiro (RJ), Brazil.

Pharmacist, Hospital Universitário Pedro Ernesto (Pedro Hernesto University Hospital) - Universidade do Estado do Rio de Janeiro (HUPE-UERJ) - Rio de

Janeiro (RJ), Brazil.

PhD - Visiting Professor of Dermatology, Faculdade de Ciências Médicas, Universidade do Estado do Rio de Janeiro (UERJ) - Rio de Janeiro (RJ), Brazil.

(C2013 by Anais Brasileiros de Dermatologia 


\section{INTRODUCTION}

Iodine, which was originally obtained from seaweed early in the $19^{\text {th }}$ century, was initially used in the treatment of thyroid disorders only. Over time, new applications made the drug useful and versatile, especially when treatment of inflammatory, immunemediated or infectious diseases fails. Psoriasis, eczema, lupus vulgaris and syphilis are examples of old targets of iodine. ${ }^{1}$ It was later used in the treatment of inflammatory dermatoses such as erythema nodosum, erythema multiforme and granuloma annulare; neutrophilic dermatoses such as Sweet's syndrome and pyoderma gangrenosum; and infectious dermatoses such as sporotrichosis and zygomycosis. ${ }^{1,2}$

Powerful new drugs replaced potassium iodide in dermatology practice, under the pretext that its therapeutic dose was too close to being toxic. On the other hand, better understanding of its mechanism of action resulted in new questions regarding its optimal dose and proper use, generating optimistic future perspectives for a known, safe, inexpensive and effective drug.

The aim of this paper is to show the versatility of an old drug that continues to be a safe and effective therapeutic option for the treatment of skin diseases, as long as it is properly prescribed and administered. We will discuss topics such as pharmacology, mechanism of action, indications and contraindications, and appropriate manipulation of the drug.

\section{METHODS}

As this is an old drug which was forgotten over the years, there are no randomized, placebo-controlled or double-blind studies on its use. The exception is an article about new pediatric dosage. ${ }^{3}$ This makes it difficult to carry out meta-analysis studies. The search on several databases using health descriptors defined by the Virtual Health Library (VHL Bireme) for potassium iodide - potassium iodide, saturated solution of potassium iodide - alone or with the phrase "AND dermatology" shows few articles on its use for specific dermatoses and in cases of nuclear accidents and thyroid disorders, in addition to reports of adverse effects.

\section{PHARMACOLOGICAL ASPECTS AND MECHA- NISM OF ACTION}

Potassium iodide (KI) is a salt composed of $76 \%$ of iodine and $23 \%$ of potassium which presents itself as transparent or white hexahedral crystals. ${ }^{1,4}$ "It is photosensitive and has slightly hygroscopic properties, being highly soluble in water." ${ }^{\prime 4}$ Its solubility limit varies depending on the solvent used. One gram (1 g) of the solute is soluble in $0.7 \mathrm{~mL}$ of water, $0.5 \mathrm{~mL}$ of boiling water, $22 \mathrm{~mL}$ of alcohol and $2 \mathrm{~mL}$ of glycerol. The solution has neutral to alkaline properties. ${ }^{4,5}$

"Iodine is poorly absorbed when applied to the skin. By the oral route, solutions of iodide salts are converted into iodine, which is transported and concentrated in the thyroid gland. The remainder is eliminated in the urine, and a small amount appears in the feces, saliva and sweat. It is excreted in breast milk and goes through the placenta." ${ }^{4}$

The various hypotheses regarding its mechanism of action justify the therapeutic versatility of iodide, which helps to protect the thyroid gland in nuclear accidents or gland disorders, in interactions with cells of the immune system and in direct action against infectious agents. Some of them are exemplified below.

Diseases whose pathogenesis involves the action of neutrophils respond well to iodide. It has been demonstrated that iodine, as well as dapsone, has the ability to suppress the production of toxic oxygen intermediates by polymorphonuclear cells and thus exert its anti-inflammatory effect. ${ }^{6}$ It also inhibits neutrophil chemotaxis, which is observed in vivo in peripheral blood when KI is taken by the oral route at a dose of $15 \mathrm{mg} / \mathrm{kg} /$ day for three days. ${ }^{7}$ It is speculated that iodine participates in halogenation reactions by myeloperoxidases, which are fundamental for the action of phagocytes. ${ }^{8}$ This mechanism also helps to understand, in part, the usefulness of this medicine against infectious diseases.

When topical, iodide acts as a disinfectant and an antiseptic. ${ }^{4}$ The ability of potassium iodide to directly destroy microorganisms continues to be speculated. Although the pharmacological literature states that potassium iodide has no antifungal activity in vitro, a study shows that cell lysis occurs when Sporothrix schenckii yeast is exposed to increasing concentrations of the drug through the release of lysosomal enzymes. ${ }^{4,9}$ Also, considering the immunological action of iodide in vivo, it is possible that it has some direct effect on the infectious agent. However, more studies are needed to confirm these mechanisms of action.

The immunomodulatory characteristic of the drug justifies its mechanism of action in relation to other inflammatory and immune-mediated disorders. However, the exact target of the complex immunological pathway on which iodide acts in each of these diseases is unknown. The lack of scientific investigations in this area could be justified by the lack of interest from the pharmaceutical industry in this old and unprofitable drug. 


\section{NON-DERMATOLOGICAL INDICATIONS}

\section{Thyroid diseases}

It is the most classic and pioneer indication regarding therapeutic experiences. Iodine is essential for the metabolism of the thyroid gland in order for it to maintain homeostasis resulting from the action of hormones. In cases of deficiencies that cause hypothyroidism and goiter, iodine supplementation is important. Hyperthyroidism can also be treated with radioiodine ablation when there are hormone-secreting solitary hot nodules. Radioiodine ablation can also be used to treat toxic multinodular goiter. Some cases of Graves' disease can also be treated this way, especially in cases that are refractory to antithyroid agents. ${ }^{10,11}$ Iodine is also used as a radioactive tracer in thyroid scintigraphy.

\section{Respiratory tract diseases}

Potassium iodide can be used as expectorant syrup at a concentration of $2 \%(20 \mathrm{mg} / \mathrm{mL})$ in cases of infectious diseases of the respiratory tract or in cases of pulmonary diseases in which anatomical changes impair expectoration, such as emphysema and cystic fibrosis. It acts as an "irritating" expectorant whose mechanism of action will occur by direct irritation of the glands of the respiratory mucosa. ${ }^{4,12}$

\section{Nuclear accidents}

Potassium iodide has been used to block the absorption of radioactive iodine (131) by the thyroid gland through saturation of the receptors in case of nuclear accidents, such as the one that occurred at the Chernobyl Nuclear Power Plant. It reduces the risk of thyroid cancer and hypothyroidism induced by radioactive iodine. It is administered in tablets, generally in a single dose a few hours after exposure to radiation, and its dosage varies according to age. ${ }^{13}$

\section{Colposcopy}

Iodine is also used in diagnostic tests such as colposcopy. The iodine solution, or Lugol's solution, used in Schiller's test stains glycogen-rich areas. In neoplastic cells, the cytoplasm is smaller because the size of the nucleus increases due to greater DNA replication. Thus, iodine-negative areas will reveal the site to be biopsied. ${ }^{14}$

\section{DERMATOSES}

\section{Infectious dermatoses}

Topical iodine has bactericidal, antiseptic and disinfectant effects. ${ }^{4}$ In the past, it was used to treat syphilis and lupus vulgaris. ${ }^{1}$ Currently, it is used to treat some diseases of infectious etiology.

\section{Sporotrichosis}

The saturated solution of potassium iodide (SSKI) has been the first choice for the treatment of lymphocutaneous and fixed cutaneous forms of sporotrichosis since 1900.1,15,16,17 Its efficacy and low cost allowed this drug to be safely used for a long period of time. However, the ease of dosage of itraconazole, which was introduced in the 1990s, caused it to be considered the first-line drug in some centers, although it is more expensive and not different from SSKI in terms of efficacy. In the main international guidelines on the treatment of this disease, the authors classify the different therapeutic options according to levels of evidence and scientific quality. SSKI and itraconazole are at the same level, that is, IIA. Therefore, they are equally effective and indicated as a therapeutic option for the treatment of lymphocutaneous and fixed cutaneous forms of sporotrichosis (Table 1$).^{18}$

TABLE 1: Strength of recommendation and quality of scientific evidence

\begin{tabular}{|c|c|}
\hline Category, grade & Definition \\
\hline \multicolumn{2}{|c|}{ Strength of recommendation } \\
\hline A & Good evidence to support a recommendation for use. \\
\hline B & Moderate evidence to support a recommendation for use \\
\hline $\mathrm{C}$ & Poor evidence to support a recommendation \\
\hline \multicolumn{2}{|c|}{ Quality of evidence } \\
\hline I & Evidence from $\geq 1$ properly randomized, controlled trial \\
\hline II & $\begin{array}{l}\text { Evidence from } \geq 1 \text { well-designed clinical trial, without randomization; from cohort or } \\
\text { case-controlled analytic studies (preferably from }>1 \text { center); from multiple time-series; } \\
\text { or from dramatic results from uncontrolled experiments }\end{array}$ \\
\hline III & $\begin{array}{l}\text { Evidence from opinions of respected authorities, based on clinical experience, descrip- } \\
\text { tive studies or reports of expert committees }\end{array}$ \\
\hline
\end{tabular}




\section{Entomophthoromycoses}

Entomophthoromycoses are subcutaneous mycoses caused by zygomycetes of the genus Basiodiobolus and Conidiobolus. They can be treated with SSKI, which is considered the gold standard treatment even when compared to the most recent antifungal drugs. Case reports show satisfactory results even in exuberant cases, with good cure rates. ${ }^{19}$

\section{Other}

The use of SSKI has been described in the literature as a therapeutic alternative for the treatment of some infections, especially when it is impossible to use other medications. Surgical procedures such as electrocoagulation, exeresis, surgical drainage, thermotherapy or cryotherapy may often be associated. Here are some indications: chromomycosis, mycetoma, cutaneous nocardiosis, cutaneous cryptococcosis and human pythiosis. Therapeutic success is directly linked to the size and duration of the lesion and to the immunological status of the host. ${ }^{1,20,21,22}$

\section{Inflammatory and immune-mediated dermatoses}

The two best indications in this group are neutrophilic dermatoses and panniculitis. ${ }^{1,2}$ The pathophysiology of pyoderma gangrenosum, Sweet's syndrome and Behçet's disease involves the action of neutrophils. ${ }^{1}$ These cells are especially present in early stages, when the intense attraction and toxicity of polymorphonuclear cells produce an exuberant inflammatory response and sterile purulent discharge. Behçet's disease exhibits clear manifestations of this mechanism, such as acne, hypopyon and aseptic meningitis. Potassium iodide has an inhibitory effect on the chemotaxis of neutrophils and on the production of toxic radicals by these cells, which justifies its use in this group of disorders. ${ }^{6,723,24}$

It is possible to assume that potassium iodide has an important anti-inflammatory role in panniculitis, since the patients that show better response also present systemic symptoms and increased C-reactive protein. It usually improves fast, with fever, pain and erythema reduction in two days and complete remission in up to two weeks. The main indications are the following: erythema nodosum, nodular vasculitis and subacute nodular migratory panniculitis. ${ }^{1,2}$

\section{Miscellaneous}

Potassium iodide has been successfully used for the treatment of erythema multiforme, even when associated with infection with herpes simplex; granuloma annulare, including reports of good response to widespread cases of the disease; Erythema annulare centrifugum; and Wegener's granulomatosis., ${ }^{1,25}$

\section{PRESENTATION AND DOSAGE}

The recommended dose of potassium iodide to treat infectious diseases varies from 4 to $6 \mathrm{~g}$ / day or 6 to $7.5 \mathrm{~g} /$ day for adults, depending on the scientific reference. The pediatric dose is about half or a third of the adult dose. . $17,26,27,28^{2}$

However, the recommended dose for inflammatory dermatoses is lower. It is approximately $1 \mathrm{~g} /$ day for adults, taken in three doses., ${ }^{1,27,28}$

As an expectorant, the syrup is formulated at $2 \%(20 \mathrm{mg} / \mathrm{mL})$ and administered at a dose of $5 \mathrm{~mL}, 3-$ $4 \mathrm{x} /$ day. $^{4}$

To make its use more convenient, potassium iodide is administered in the form of a saturated solution (SSKI). ${ }^{1}$ A saturated solution should be understood as one in which the addition of any solute will result in its precipitation. Considering the solubility limit for distilled water, which is the vehicle usually used, we found that $1 \mathrm{~g}$ of the salt to a volume of 0.7 $\mathrm{mL}$ of this solvent results in a solution of approximately $1.42 \mathrm{~g} / \mathrm{mL}{ }^{4}$

A discrepancy regarding the dosage of SSKI to be administered is observed in the scientific literature. This can be evidenced in the formulations recommended by WHO or even by some reference books and scientific articles on pharmacology, which define the concentration of the saturated solution of potassium iodide as $1 \mathrm{~g} / \mathrm{mL}^{4,17,26-31}$ They probably use already prepared saturated solutions and dilute them to obtain a concentrated solution (not saturated) of $1 \mathrm{~g} / \mathrm{mL}$. In Brazil, we typically use the pure potassium iodide salt (PA) in the therapeutic formulations.

It is important to have all these considerations in mind before administering the drug to a patient so that the actual dose can be known. Toxicity or absence of therapeutic response is often due to inadequate dosage. Most studies address the number of drops to be administered in the treatment, without even mentioning the characteristics of the solution and the volume of drops used, that is, the amount in grams that is being administered to the patient.

For these reasons, it can be inferred that the knowledge and standardization of the proper use of SSKI are important so that treatment can be tolerable, safe and correct.

When using pure potassium iodide crystals (PA), the correct formula for a final volume of $100 \mathrm{~mL}$ is $100 \mathrm{~g}$ of salt to $70 \mathrm{~mL}$ of distilled water or $50 \mathrm{~g}$ of salt to $35 \mathrm{~mL}$ of water if the desired final volume is $50 \mathrm{~mL}$.

Considering a standard dropper in which each drop has a volume of $0.05 \mathrm{~mL}$, there will be $0.07 \mathrm{~g}$ of KI per drop $(1.42 \mathrm{~g} / \mathrm{mL})$ in the solution. Thus, by administering 20 drops of the solution $3 x /$ day, the daily intake of potassium iodide is approximately $4 \mathrm{~g}$. It is also possible to use the concentrated solution, in 
which there is $1 \mathrm{~g}$ of potassium iodide in each $\mathrm{mL}$ of water. However, if we consider the same drop volume of $0.05 \mathrm{~mL}$, the daily dose taken by administering 20 drops $3 x /$ day will be $3 g$.

The studies on dosage recommendation are based on the most classic indication, that is, on the treatment of sporotrichosis. According to the official publication of IDSA (Infectious Diseases Society of America), the recommendation for the treatment of lymphocutaneous or fixed cutaneous sporotrichosis is 40-50 drops $3 x$ / day of a saturated solution, but they do not say how the solution is prepared..$^{18}$ If it were saturated, the daily total dose would be unbearable, between 8.4 and $10.5 \mathrm{~g} /$ day. It is possible that they have considered the concentrated solution, even though the daily dose of $6-7.5 \mathrm{~g}$ is not always well tolerated.

Another standardization to be reviewed is related to drop volume. A standard dropper usually has $0.05 \mathrm{~mL} /$ drop, but there are variations. ${ }^{32}$ In Brazil, we usually administer 4-6g/day in the treatment of sporotrichosis, which is taken in three doses (Table 2). ${ }^{1}$ ${ }^{17,26-28}$ In summary, no matter whether the solution is concentrated or saturated, it is important to know the formulation being used so that the daily dose for inflammatory, infectious or immune-mediated diseases can be adjusted.

TABLE 2: Calculation of the actual dose of potassium iodide per drop, considering the two formulations more commonly used

\begin{tabular}{lll}
\hline & $\begin{array}{l}\text { Concentrated } \\
\text { solution } \\
(1 \mathrm{~g} / \mathrm{mL})\end{array}$ & $\begin{array}{l}\text { Saturated } \\
\text { solution } \\
(1.42 \mathrm{~g} / \mathrm{mL})\end{array}$ \\
\hline $\begin{array}{l}\text { Concentration } / \\
\text { standard drop } \\
(0.05 \mathrm{ml})\end{array}$ & $0.05 \mathrm{~g} /$ drop & $0.07 \mathrm{~g} /$ drop \\
\hline
\end{tabular}

\section{CONTRAINDICATIONS AND ADVERSE EFFECTS}

The use of KI is contraindicated in cases of previous thyroid diseases such as hypo or hyperthyroidism, presence of nodules and thyroid cancer. Family history of thyroid disease is a relative contraindication. However, positivity for autoantibodies such as anti-TPO antibodies (anti-thyroid peroxidase) and TRAb (TSH receptor antibodies) show a predisposition to autoimmune thyroid diseases that can be triggered by exposure to iodine. ${ }^{1,33}$

$\mathrm{KI}$ is also contraindicated in patients with any type of allergy to iodine. ${ }^{4,28,29,30}$ Its use should be avoided in patients with chronic renal failure because of the presence of potassium in its formulation and is proscribed in those whose renal function is greatly impaired. Similarly, those using potassium-sparing diuretics or angiotensin-converting-enzyme inhibitors should be closely monitored. ${ }^{1,428}$

It is prudent to avoid the concomitant use of other medications such as lithium, because of its drug interaction, and of medications containing iodine in its formulation such as amiodarone. ${ }^{4,28}$

Transplant patients and patients with cancer, a history of alcoholic disease, poorly controlled diabetes mellitus and insulin-dependency, autoimmune diseases and immunosuppressive characteristics such as AIDS, and patients who use corticosteroids and immunosuppressive medications should not use this medicine, for its mechanism of action affects the immune system. Active tuberculosis is also included in this group..$^{30}$

It should not be used by pregnant and lactating women, for it causes neonatal hypothyroidism, thyromegaly, fetal airway obstruction and prolonged labor, being among the category D drugs. ${ }^{1,428,30}$

It should also not be administered to patients with Addison's disease, since they do not only present an autoimmune condition but also changes similar to those that occur with the use of angiotensin-converting-enzyme inhibitors. ${ }^{28}$

Regarding infectious diseases, KI is not recommended in cases of extensive disease or in cases of involvement of internal organs such as systemic or disseminated cutaneous forms of sporotrichosis, because it is believed that these patients' immune system is impaired. ${ }^{18}$

Adverse effects, usually mild to moderate, may occur due to the high doses administered, especially for the treatment of infectious skin disorders. They are often related to the digestive system, with a predominance of gastrointestinal intolerance and a metallic or bitter taste in the mouth. ${ }^{1,30}$

To relieve these symptoms, it is recommended to start the treatment with low doses of the drug, usually five drops of $1.42 \mathrm{mg} / \mathrm{mL}(0.35 \mathrm{~g})$ three times a day, with daily increases of a drop every time the medicine is taken until the target dosage is reached, for both adults and children. . $^{1,17,18,29,30}$ Another recommendation is to take the medicine after meals, with the intake of juice or milk soon afterwards. ${ }^{29}$ Some pharmacological references recommend mixing the medicine with these drinks. ${ }^{1,17,30}$ Reducing the dose every time the medicine is taken often eliminates the gastrointestinal complaint without reducing its efficacy.

Due to the presence of large amounts of iodine in the drug, it is possible that it has some effects on the metabolism of the thyroid. There is a physiological 
mechanism of autoregulation in the human body that aims to keep the pool of stored iodine balanced. Thus, an excess of iodine causes an acute inhibitory effect with a temporary increase in TSH called adaptive block. However, there are escape mechanisms that help maintain the normal function of the gland. ${ }^{1,10}$

The Wolff-Chaikoff phenomenon is described as an interruption in the thyroid hormone synthesis due to the inability of the thyroid to overcome the acute inhibitory effect resulting from inefficient escape mechanisms in individuals with underlying thyroid disorders, especially Hashimoto's thyroiditis. In these cases, there is axis suppression and increased TSH levels, with consequent hypothyroidism (decreased free T4)., 1,33

On the other hand, if the patient presents autonomous hormone production in toxic multinodular goiter or in Graves' disease, there may be hyperthyroidism or thyrotoxicosis, which is called JodBasedow. ${ }^{1,33}$

Other adverse effects are occasionally found in the scientific literature, such as acneiform eruption, dermatitis herpetiformis, pustular psoriasis, bullous pemphigoid and iododerma, possibly related to the action on the chemotaxis of polymorphonuclear cells, with iododerma being the most frequent condition in patients with underlying systemic diseases. The syndrome caused by iodine poisoning is called iodism. It is characterized by conjunctival hyperemia, lacrimation, blurred vision, rhinorrhea and sialorrhea. ${ }^{1,28,30}$
As with any drug, allergic reactions such as urticaria and angioedema should be considered. ${ }^{1,29}$ Cases of congestive heart failure with pulmonary edema and cases of toxicity related to potassium iodine, such as renal dysfunction, cardiac arrhythmia and metabolic acidosis, have been described. ${ }^{30,34,35}$ Headaches, arthralgia and prolonged fever have also been reported. ${ }^{1,30}$

\section{CONCLUSION}

Despite being used in Medicine for over a century, potassium iodine remains a good therapeutic option for the treatment of several dermatoses as a drug of first or second choice and may be part of the dermatologist's therapeutic arsenal. When treatment with potassium iodide is considered, it is important to know the exact dose being administered, since the toxicity is directly related to dosage and not to the drug. This involves knowing the formulation being used and the effective dose per drop (in grams) for each individual and therapeutic indication. The toxicity of a drug alone does not constitute a reason to abandon its use, since deeper knowledge of the drug may generate benefits to the patient who does not have access or cannot use other medications due to high cost, adverse effects, drug interactions or even therapeutic failure, in case adverse effects can be controlled, of course. Simply recommending the number of drops may lead to misuse and undue dose administration with risks for the patient. 


\section{REFERENCES}

1. Sterling JB, Heymann WR. Potassium iodide in dermatology: a 19th century drug for the 21 st century uses, pharmacology, adverse effects, and contraindications. J Am Acad Dermatol. 2000;43:691-7.

2. Horio T, Danno K, Okamoto H, Miyachi Y, Imamura S. Potassium iodide in erythema nodosum and other erythematous dermatoses. J Am Acad Dermatol.1983;9:77-81

3. Cabezas C, Bustamante B, Holgado W, Begue RE. Treatment of cutaneous sporotrichosis with one daily dose of potassium iodide. Pediatr Infect Dis J. 1996; 15:352-4.

4. Sweetman S. Martindale: the complete drug reference. United Kingdom: Pharmaceutical Press; 2009. p. 2169-70.

5. Kirk TG. The Merck index. 12th ed.New York: Merck \& Co; 1996 p. 7809

6. Miyachi Y, Niwa Y. Effects of potassium iodide, colchicine and dapsone on the generation of polymorphonuclear leukocyte-derived oxygen intermediates. $\mathrm{Br}$ Dermatol. 1982;107:209-14.

7. Honma K, Saga K, Onodera H, Takahashi M. Potassium iodide inhibits neutrophil chemotaxis. Acta DermVenereol. 1990;70:247-9.

8. Torres-Mendonza BM, Vásquez-Valls E, González-Mendonza A. Effect of potassium iodide on the immune response in the sporotrichosis. Rev Iberoam Micol. 1997;14:98-100.

9. Hiruma M, Kagawa S. Ultrastructure of Sporothrixschenckii treated with iodinepotassium solution. Mycopathologia. 1987;97:121-7

10. Vaisman M, Rosenthal D, Carvalho DP. Enzymes involved in thyroid iodide organification. Arq Bras Endocrinol Metab.2004;48:7-13

11. Albino CC, Takahashi MH, Senhonni Junior S, Graf H. Inquérito sobre 0 uso de iodo-131 no Brasil. Arq Bras Endocrinol Metab.2001;45:558-62.

12. Prograd.uff.br [Internet]. Farmacologia do aparelho respiratório [acesso 11 Dez 2012]. Disponível em: http://www.proac.uff.br/farmacoclinica/sites/default/files/ 9 APARELHO RESPIRATORIO Tosse e antigripais.pdf

13. Adalja AA. Use of potassium iodide (KI) in a nuclear emergency.BiosecurBioterror 2011;9:405-7.

14. Conceição JCJ, Silveira CMG, Bandeira D. Neoplasias intra-epiteliais cervicais e câncer do colo do útero. In: Conceição JCJ, editor. Ginecologia Fundamental. São Paulo: Atheneu; 2005. p. 185

15. Kauffman CA. Old and new therapies for sporotrichosis. Clin Infect Dis 1995;21:981-5

16. Kauffman CA. Sporotrichosis. Clin Infet Dis.1999;29:231-6.

17. Ramos-e-Silva M, Vasconcelos C, Carneiro S, Cestari T. Sporotrichosis. Clin Dermatol. 2007;25:181-7.

18. Kauffman CA, Bustamante B, Chapman SW, Pappas PG; Infectious Diseases Society of America. Clinical Practice Guidelines for the Management of Sporotrichosis: 2007 Update by the Infectious Diseases Society of America. IDSA Guidelines for management of Sporotrichosis. Clin Infect Dis. 2007;45:1255-65.

19. Mendiratta V, Karmakar S, Jain A, Jabeen M. Severe cutaneous zygomycosis due to Basidiobolusranarum in a young infant. Pediatr Dermatol.2012;29:121-3.

20. Narendranath S, Sudhakar GK, Pai MR, Kini H, Pinto J, Pai MR. Safety and efficacy of oral potassium iodide in chromoblastomycosis. Int $\mathrm{J}$ Dermatol. 2010;49:341-3.

21. Khan FA, Hashmi S, Sarwari AR. Multiple subcutaneous mycetomas caused by Pseudallescheriaboydii: response to therapy with oral potassium iodide solution. J Infect. 2010;60:178-81.

22. Aozasan N, Kiso M, Kaneko T. Primary lymphocutaneousnocardiosis due to Nocardiabrasiliensis which was successfully treated with only oral potassium iodide. J Dermatol. 2011;38:826-8.
23. Asahina A, Minatami Y, Tada Y, Mitsui H, Tamaki K. Successful treatment of pyodermagangrenosum with potassium iodide. Acta DermVenereol. 2006;84-5.

24. Koguchi H, Arita K, Yamane N, Shinkuma S, Shimizu H. Erythema annularecentrifugum-like neutrophilicdermatoses: effects of potassium iodide. Acta DermVenereol. 2012;92:333-4

25. Smith JB, Hansen CD, Zone JJ. Potassium iodide in the treatment of disseminated granuloma annulare. J Am Acad Dermatol.1994;30:791-2.

26. Campbell I, Pacheco TMV. Esporotricose. In: Zaitz C, Marques SA, Ruiz LRB, Framil VMS editores. Compêndio de micologia médica. Rio de Janeiro: Guanabara Koogan; 2010. p. 349

27. Sampaio S, Rivitti E. Terapêutica sistêmica. In: Sampaio S, Rivitti E, editores. Dermatologia. São Paulo: Artes médicas; 2007. p. 1437-1438.

28. Nunley JR, Wolverton S, Darst M. Systemicdrugs. In: Bolognia JL, Jorizzo JL, Rapini RP editors. Dermatology.2nd ed. Madri: Mosby Elsevier; 2008. p. 2017-8.

29. Bennett JE. Agentesantifúngicos. In: Gilman AG, Goodman AG. Goodman \& Gilman: as bases farmacológicas da terapêutica. 10.ed. Rio de Janeiro: Guanabara-Koogan, 2001. p.977-8.

30. Who.int [Internet]. WHO Model Prescribing Information: Drugs used in skin diseases [cited 2012Dez12]. Disponível em: http://apps.who.int/medicinedocs/en/d/ Jh2918e/24.12.html\#Jh2918e.24.12

31. Donadel KW, Reinoso YD, Oliveira JC, Azulay RD. Esporotricose. AnBrasDermatol.1993;68:42-52.

32. Peet M, Yates RA, Shields AG. Dose-response relationship for mydriasis produced by topical ocular tyramine in man. Br J Clin Pharmacol. 1980;9:96-8.

33. Heymann WR. Potassium iodide and the Wolff-Chaikoff effect: relevance for the dermatologist. J Am Acad Dermatol. 2000;42:490-2.

34. Hollander L, Fetterman GH. Fatal iododerma: the eleventh case reported in the literature. Arch Dermatol Syphilol. 1936;34:228-41.

35. Miller DW. Extrathyroidal benefits of iodine. J Am Phys Surg. 2006;11:106-10.
MAILING ADDRESS:

Rosane Orofino Costa

Av. 28 de Setembro, $872^{\circ}$ andar

Vila Isabel

20551-030 - Rio de janeiro - RJ

E-mail address: rosaneorofino@globo.com

How to cite this article: Orofino-Costa R, Macedo PM, Carvalhal A, Bernardes-Engemann AR. Use of potassium iodide in Dermatology: updates on an old drug. An Bras Dermatol. 2013;88(3):396-02. 